\title{
Cellulose-based graft copolymers prepared by simplified electrochemically mediated ATRP
}

\author{
P. Chmielarz*
}

Department of Physical Chemistry, Faculty of Chemistry, Rzeszów University of Technology, Al. Powstańców Warszawy 6 , 35-959 Rzeszów, Poland

Received 18 August 2016; accepted in revised form 30 September

\begin{abstract}
Brush-shaped block copolymer with a dual hydrophilic poly(acrylic acid)-block-poly(oligo(ethylene glycol) acrylate) (PAA- $b$-POEGA) arms was synthesized for the first time via a simplified electrochemically mediated ATRP (seATRP) under both constant potential electrolysis and constant current electrolysis conditions, utilizing only 30 ppm of catalyst complex. The polymerization conditions were optimized to provide fast reactions while employing low catalyst concentrations and preparation of cellulose-based brush-like copolymers with narrow molecular weight distributions. The results from proton nuclear magnetic resonance $\left({ }^{1} \mathrm{H}\right.$ NMR) spectral studies support the formation of cellulose-based graft (co)polymers. It is expected that these new polymer brushes may find application as $\mathrm{pH}$ - and thermo-sensitive drug delivery systems.
\end{abstract}

Keywords: polymer synthesis, cellulose-based graft polymers, seATRP

\section{Introduction}

The most abundant renewable biomacromolecule, cellulose has attracted considerable attention in recent years due to its biodegradable, biocompatible and renewable character [1-5]. As its anhydroglucopyranose unit contains reactive hydroxyl groups, cellulose has potential use in the design of advanced polymeric materials $[6,7]$.

A variety of approaches has been reported for the modification of cellulose by graft polymerization, provides a significant route that combines the advantages of using natural cellulose and synthetic macromolecules in a wide range of potential applications, such as new materials for drug delivery devices, coatings, sorption agents, and membranes $[2,3,8]$. One of them is the 'grafting-from' technique, which uses a multi-functional initiator to initiate atom transfer radical polymerization (ATRP) [9-11].

Numerous monomers have been grafted from cellulose via ATRP, such as methyl methacrylate $[2,3,11$,
12], $N, N$-dimethylamino-2-ethyl methacrylate [5, 13], di(ethylene glycol) ethyl ether acrylate [12], styrene [2], $N$-isopropylacrylamide [14, 15], and 2methacryloyloxyethyl phosphorylcholine [10], but synthesis of cellulose-graft-(poly(acrylic acid)-blockpoly(oligo(ethylene glycol) acrylate) (Cell-g-(PAA$b$-POEGA) has not yet been reported. It is expected that these synthesized graft copolymers have great potential in biomedical, such as tissue engineering scaffolds with double-responsive and antifouling properties. Linear form of PAA has been one of the most extensively studied industrially important watersoluble polymer [16]. It has significant $\mathrm{pH}$ response, which is mainly due to high concentrations of $-\mathrm{COOH}$ groups $[17,18]$, and therefore it is widely used as $\mathrm{pH}$-sensitive drug delivery systems [19-21]. Meanwhile, POEGA is a versatile co-monomer, which has hydrophilic, temperature-responsive, nontoxic and biocompatible characteristics [22-25]. What

$\overline{{ }^{*} \text { Corresponding author, e-mail: p chmiel@prz.edu.pl }}$

(C) BME-PT 
is important, it exhibit antifouling effects to a wide variety of proteins [23].

ATRP is one of the most utilized technique to produce polymers with precise and complex architectures, predetermined molecular weight distribution $\left(M_{\mathrm{w}} / M_{\mathrm{n}}, \mathrm{MWD}\right)$, degrees of polymerization (DP), and high end group fidelity [26-29]. The advent of (re)generation of transition metal with ligands catalysts concepts allows use of ppm level of catalyst for ATRP, such as simplified electrochemically mediated ATRP (seATRP) [30], which uses electric current as external stimulus to reduce deactivator to the activator species [30-34]. seATRP can be conducted at a fixed $E_{\text {app }}$ (constant potential electrolysis conditions) in a three-electrode cell, with working electrode (WE), counter electrode (CE), and reference electrode (RE). On the other hand, electrolysis under constant current conditions $\left(I_{\mathrm{app}}\right)$ is particularly attractive from an industrial standpoint, because it eliminates the RE compared with the electrolysis under controlled potential conditions, providing twoelectrode system (WE and CE), furthermore it requires less expensive instrumentation (current generator vs potentiostat). In both cases, if the reduction of deactivator to activator occurs at the WE surface the reduced activator is spread out into the bulk reaction mixture by vigorous stirring. Activator reacts with the initiator to form radicals and the deactivating complex. The radical species propagate to form polymeric chains by reacting with the monomer, or are deactivated back to dormant species by deactivator.

The main objective of this article is to report the first example of the preparation of well-defined cellulosebased graft (co)polymers, consisting of the respective hydrophilic PAA and dual hydrophilic PAA- $b$ POEGA arms by seATRP under both constant potential electrolysis and constant current electrolysis conditions. It was presented that polymerization conditions were optimized to provide fast reactions while employing low catalyst concentrations and preparation of brush-like copolymers with narrow MWDs.

\section{Experimental section 2.1. Materials}

Microcrystalline cellulose (MCC, AVICEL PH-101, with a 'typical' $M_{\mathrm{n}}=10800, M_{\mathrm{w}} / M_{\mathrm{n}}=3.00$ ) [35] with DP of 67 was obtained from Aldrich and dried under vacuum at $100{ }^{\circ} \mathrm{C}$ for $24 \mathrm{~h}$. Ionic liquid 1-allyl-3- methylimidazolium chloride (AMIMCl, 98\%) was purchased from Alfa Aesar, USA. 2-Bromoisobutyryl bromide (BriBBr, 98\%), dimethylformamide (DMF, $99.9 \%$ ) tetrahydrofuran (THF, $>99.9 \%$ ), methanol ( $\mathrm{MeOH},>99.8 \%$ ), tetrabutylammonium perchlorate (TBAP, $>98 \%$ ), copper(II) bromide ( $\mathrm{Cu}^{\mathrm{II}} \mathrm{Br}_{2}, 99.9 \%$ ), $n$-butanol ( $>99.7 \%)$, sulfuric acid ( $>95 \%$ ), trifluoroacetic acid (TFA, >99\%), dichloromethane (DCM, $>99.5 \%$ ), acidic ion-exchange resin (Dowex Marathon), and sodium hydroxide $(\mathrm{NaOH},>98 \%)$, were purchased from Aldrich. Tris(2-pyridylmethyl) amine (TPMA) was prepared according to a procedure [36]. Stock solutions of $\mathrm{Cu}^{\mathrm{II}} \mathrm{Br}_{2}$ and TPMA were prepared according to a reference [32]. tert-Butyl acrylate ( $t \mathrm{BA},>99 \%$, Aldrich) and oligo(ethylene glycol) acrylate (OEGA, $>99 \%$, Aldrich) were passed through a column filled with basic alumina prior to use to remove inhibitor. Platinum $(\mathrm{Pt})$ wire, $\mathrm{Pt}$ gauge mesh and Pt disk ( $3 \mathrm{~mm}$ diameter, Gamry) were purchased from Alfa Aesar, USA. Cyclic voltammetry $(\mathrm{CV})$ and preparative electrolysis were conducted in electrochemical cell kit (Gamry, USA).

\subsection{Analysis}

${ }^{1} \mathrm{H}$ NMR spectra in DMSO- $\mathrm{d}_{6}\left(\mathrm{CDCl}_{3}\right.$ for cleaved $\mathrm{P} t \mathrm{BA}$ homopolymer) used for the calculation of monomer conversion were measured using Bruker Avance $500 \mathrm{MHz}$ spectrometer according to the previous research [30]. Molecular weights and molecular weight distributions were determined by GPC (PSS columns: guard, $10^{5}, 10^{3}, 10^{2} \AA$ ), with THF eluent at $25^{\circ} \mathrm{C}$, flow rate $1.00 \mathrm{~mL} / \mathrm{min}$, with a RI detector (Viscotek, T60A). The apparent molecular weights and $M_{\mathrm{w}} / M_{\mathrm{n}}$ were determined with a calibration based on PS standards using TRISEC software. CVs and preparative electrolysis were recorded on a Metrohm Autolab potentiostat (AUT84337) using GPES EcoChemie software. The CVs and electrolysis were carried out under Ar atmosphere using a Pt disk for $\mathrm{CV}$, and $\mathrm{Pt}$ mesh for electrolysis, working electrodes. The sacrificial CE was Al wire $(l=10 \mathrm{~cm}, d=1 \mathrm{~mm})$. Values for potentials applied for electrolysis were established from CV measurements at a $100 \mathrm{mV} / \mathrm{s}$ scan rate using saturated calomel electrode (SCE; Gamry) $\mathrm{RE}$ according to the previous research [33].

\subsection{Synthesis of the cellulose}

2-bromoisobutyrate macroinitiator (Cell-Br)

The process of esterification of cellulose with $\mathrm{BriBBr}$ to obtain the macroinitiator Cell-Br was shown in 


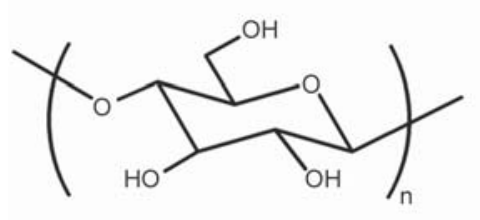

MCC

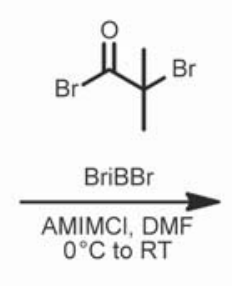

Figure 1. Synthesis of cellulose-based ATRP initiator (Cell-Br)

Figure 1 according to the procedure described in references $[2,5,37]$.

MCC (2.0 g, $12.4 \mathrm{mmol})$ was dissolved in $40.00 \mathrm{~g}$ of AMIMCl ( $25 \mathrm{~mL}$ DMF as dilute) under $80^{\circ} \mathrm{C}$ to form a yellow solution, then the mixture was cooled to room temperature (under Ar). The solution was stirred for $1 \mathrm{~h}$ at room temperature and then cooled to $0^{\circ} \mathrm{C}$. A solution of $\operatorname{BriBBr}(7.7 \mathrm{~mL}, 62.0 \mathrm{mmol})$ in DMF $(5 \mathrm{~mL})$ was added dropwise to the mixture. The reaction solution was left to warm up to room temperature and stirred for $72 \mathrm{~h}$. The resulting solution was poured into excessive deionized water and precipitated out the white floccules. The floccules (Cell-Br), was washed thoroughly with water, then filtered and dried under vacuum at $50^{\circ} \mathrm{C}$ for $48 \mathrm{~h}$ before characterization by THF GPC and ${ }^{1} \mathrm{H}$ NMR. The degree of substitution (DS) of Cell-Br was calculated from the ${ }^{1} \mathrm{H}$ NMR spectrum.

\subsection{Synthesis of Cell-g-PtBA graft polymers by seATRP}

The synthesis of Cell- $g$-P $t$ BA graft polymers was conducted under constant potential and constant current electrolysis conditions (Figure 2).

TBAP (1.37 g, 4 mmol) was placed in an electrolysis cell maintained at $50^{\circ} \mathrm{C}$ under $\mathrm{Ar}$ atmosphere. Then, $10 \mathrm{~mL}$ of Ar purged $t \mathrm{BA}(68.30 \mathrm{mmol}), 8.0 \mathrm{~mL}$ of DMF, and $41 \mu \mathrm{L}$ of $\mathrm{Cu}^{\mathrm{II}} \mathrm{Br}_{2} / 2$ TPMA stock solution (0.05 $\mathrm{M}$ in DMF) were added to the reaction cell. The $\mathrm{CV}$ was recorded (Pt disk WE, Al wire CE, SCE RE) for determining the appropriate applied potential
$\left(E_{\text {app }}=E_{\mathrm{pc}}-55 \mathrm{mV}\right)$. Then a solution of $71 \mathrm{mg}$ of Cell-Br $(0.23 \mathrm{mmol})$ in $2 \mathrm{~mL}$ of DMF was injected. The selected potential was applied using the controlled potential preparative electrolysis ( $\mathrm{Pt}$ mesh WE, Al CE, SCE RE). After this synthesis an identical reaction composition was prepared for the polymerization under multiple applied currents: $I_{\text {app }, 1}=$ $-1.32 \mathrm{~mA}(0.07 \mathrm{~h}), I_{\mathrm{app}, 2}=-0.9 \mathrm{~mA}(0.07 \mathrm{~h}), I_{\mathrm{app}, 3}=$ $-0.54 \mathrm{~mA}(0.07 \mathrm{~h}), I_{\mathrm{app}, 4}=-0.41 \mathrm{~mA}(0.07 \mathrm{~h}), I_{\mathrm{app}, 5}=$ $-0.28 \mathrm{~mA}(0.14 \mathrm{~h}), I_{\mathrm{app}, 6}=-0.22 \mathrm{~mA}(0.14 \mathrm{~h}), I_{\mathrm{app}, 7}=$ $-0.16 \mathrm{~mA}(0.14 \mathrm{~h}), I_{\mathrm{app}, 8}=-0.12 \mathrm{~mA}(0.14 \mathrm{~h}), I_{\mathrm{app}, 9}=$ $-0.08 \mathrm{~mA}(0.83 \mathrm{~h}), I_{\mathrm{app}, 10}=-0.06 \mathrm{~mA}(0.83 \mathrm{~h}), I_{\text {app }, 11}=$ $-0.05 \mathrm{~mA}(1.50 \mathrm{~h})$. At a certain interval time, an amount of reaction mixture was withdrawn to follow the monomer conversion using ${ }^{1} \mathrm{H}$ NMR. The final sample was purified by dialysis against methanol (MWCO 1000). After filtered and washed, the white solid products were collected and dried by air, dissolved in THF, passed through a neutral alumina column in order to remove catalyst, and dried under vacuum for 14 days before ${ }^{1} \mathrm{H}$ NMR characterization.

The P $t$ BA arms of cellulose-based graft polymers were cleaved by acid solvolysis according to procedure described in references [34, 38]. Therefore, the polymer sample $(100 \mathrm{mg})$ was dissolved in THF $(2 \mathrm{~mL})$ and $n$-butanol (32 mL). Concentrated sulfuric acid $(0.4 \mathrm{~mL})$ was added, and the solution was heated at $100^{\circ} \mathrm{C}$ for 7 days. The residue polymer was precipitated into methanol, washed and dried in vacuum at $50^{\circ} \mathrm{C}$ for 7 days and then characterized by GPC to examine the growth of the polymer arms with
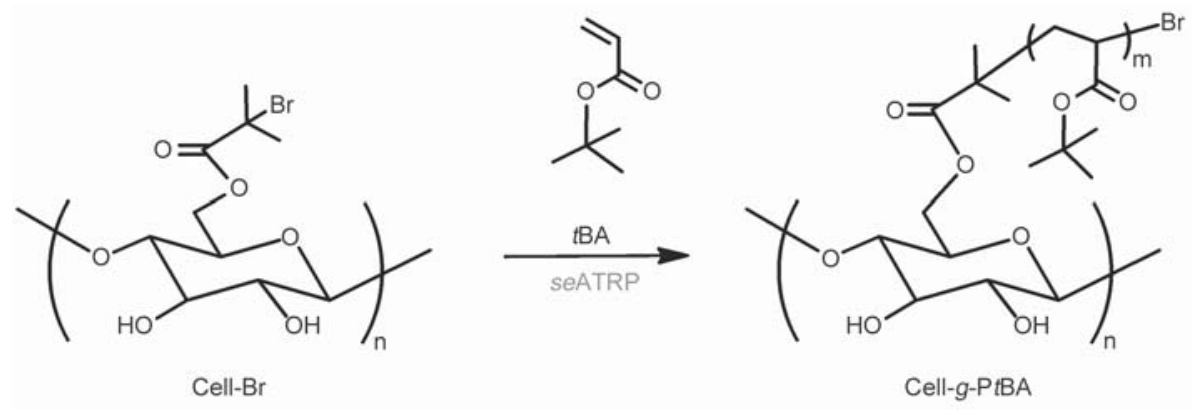

Figure 2. Synthesis of Cell- $g$-P $t$ BA graft polymers via seATRP 
monomer conversion and by ${ }^{1} \mathrm{H}$ NMR to confirm formation of $\mathrm{P} t \mathrm{BA}$ by cleaving process.

\subsection{Transformation to Cell-g-PAA graft polymers}

The PtBA blocks of cellulose-based graft polymers were hydrolysed to PAA blocks (Figure 3 ).

The Cell-g-P $t$ BA graft polymer $(5 \mathrm{~g}, 5.7 \mathrm{mmol})$ was dissolved in DCM $(60 \mathrm{~mL})$ and a 5-fold molar excess of TFA ( $2.19 \mathrm{~mL}, 28.6 \mathrm{mmol}$ ) was added (with respect to the ester groups). The mixture was stirred at room temperature for $72 \mathrm{~h}$. When hydrolyzed, the copolymers precipitate in DCM. They were separated by filtration, washed with DCM. Finally, solvent and TFA were removed by rotating evaporation, vacuum drying at $50^{\circ} \mathrm{C}$ for 7 days and characterized using ${ }^{1} \mathrm{H}$ NMR [39-42].

The PAA arms of cellulose-based graft polymers were cleaved by alkaline hydrolysis according to procedure described in reference [42]. Therefore, the polymer sample $(300 \mathrm{mg}$ ) and $600 \mathrm{mg} \mathrm{NaOH}$ were dissolved $6 \mathrm{~mL}$ of water and heated for 7 days at $80^{\circ} \mathrm{C}$. The pure linear PAA was then recovered by use of acidic ion exchange resin ( $15 \mathrm{~g})$ until reaching $\mathrm{pH}=$ 3 . The resin was removed and the aqueous solution was freeze-dried. The residue polymer was dried in vacuum at $50^{\circ} \mathrm{C}$ for 7 days and characterized by GPC and ${ }^{1} \mathrm{H}$ NMR.

\subsection{Synthesis of Cell-g-(PAA-b-POEGA) graft polymers by seATRP}

The seATRP method was also used for the chain extension of the Cell-g-PAA macroinitiator with OEGA (Figure 4).

The polymerization conditions was as follows: $[\text { OEGA }]_{0} /[$ Cell-g-PAA (per $\left.-\mathrm{Br})\right]_{0} /\left[\mathrm{Cu}^{\mathrm{II}} \mathrm{Br}_{2} /\right.$ $2 \mathrm{TPMA}]_{0}=120 / 1 / 0.0036,[\mathrm{OEGA}]_{0}=0.7 \mathrm{M}$ in DMF, $\left[\mathrm{Cu}^{\mathrm{II}} \mathrm{Br}_{2} / 2 \mathrm{TPMA}\right]_{0}=0.02 \mathrm{mM}, E_{\text {app }}=E_{\mathrm{pc}}-65 \mathrm{mV}, T=$ $50^{\circ} \mathrm{C},[\mathrm{TBAP}]_{0}=0.2 \mathrm{M}, V_{\text {tot }}=15 \mathrm{~mL}$. An identical mixture was prepared and seATRP was carried out under multiple applied currents: $I_{\mathrm{app}, 1}=-1.46 \mathrm{~mA}$ $(0.07 \mathrm{~h}), I_{\text {app }, 2}=-1.05 \mathrm{~mA}(0.07 \mathrm{~h}), I_{\text {app }, 3}=-0.77 \mathrm{~mA}$ $(0.07 \mathrm{~h}), I_{\text {app }, 4}=-0.54 \mathrm{~mA}(0.07 \mathrm{~h}), I_{\text {app }, 5}=-0.38 \mathrm{~mA}$ $(0.07 \mathrm{~h}), I_{\text {app }, 6}=-0.27 \mathrm{~mA}(0.07 \mathrm{~h}), I_{\text {app }, 7}=-0.20 \mathrm{~mA}$ $(0.07 \mathrm{~h}), I_{\text {app }, 8}=-0.15 \mathrm{~mA}(0.07 \mathrm{~h}), I_{\text {app }, 9}=-0.11 \mathrm{~mA}$ $(0.14 \mathrm{~h}), I_{\text {app }, 10}=-0.08 \mathrm{~mA}(0.14 \mathrm{~h}), I_{\mathrm{app}, 11}=-0.05 \mathrm{~mA}$ $(0.14 \mathrm{~h}), I_{\text {app }, 12}=-0.04 \mathrm{~mA}(0.14 \mathrm{~h}), I_{\text {app }, 13}=-0.03 \mathrm{~mA}$ $(1.39 \mathrm{~h}), I_{\text {app }, 14}=-0.02 \mathrm{~mA}(1.50 \mathrm{~h})$. In both cases samples were withdrawn periodically to follow the conversion ( ${ }^{1} \mathrm{H}$ NMR). The final sample was purified by dialysis water and methanol, subsequently (MWCO 1000). After filtered and washed, the white solid products were dried by air, dissolved in THF, passed through a neutral alumina column, and dried under vacuum for 14 days before NMR characterization. The PAA- $b$-POEGA blocks of cellulose-based graft copolymers were cleaved by alkaline hydrolysis

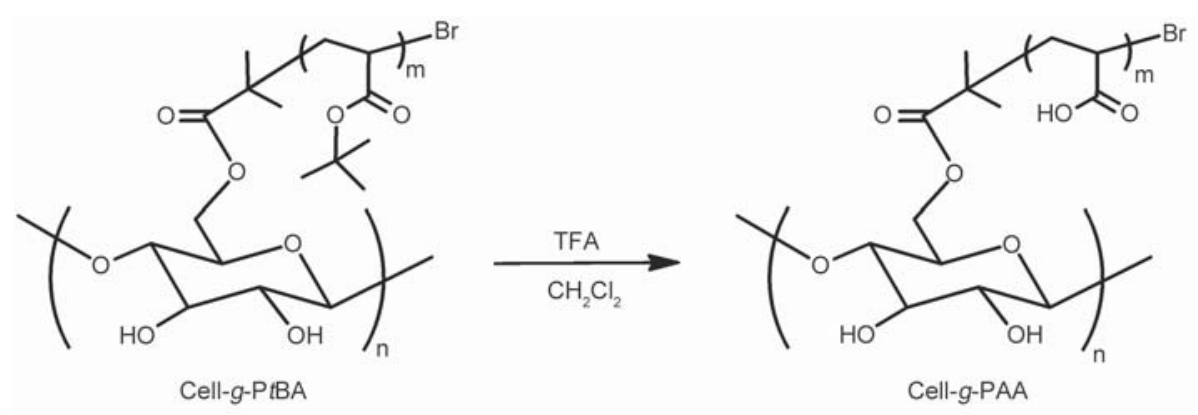

Figure 3. Transformation to Cell-g-PAA graft polymers via hydrolysis
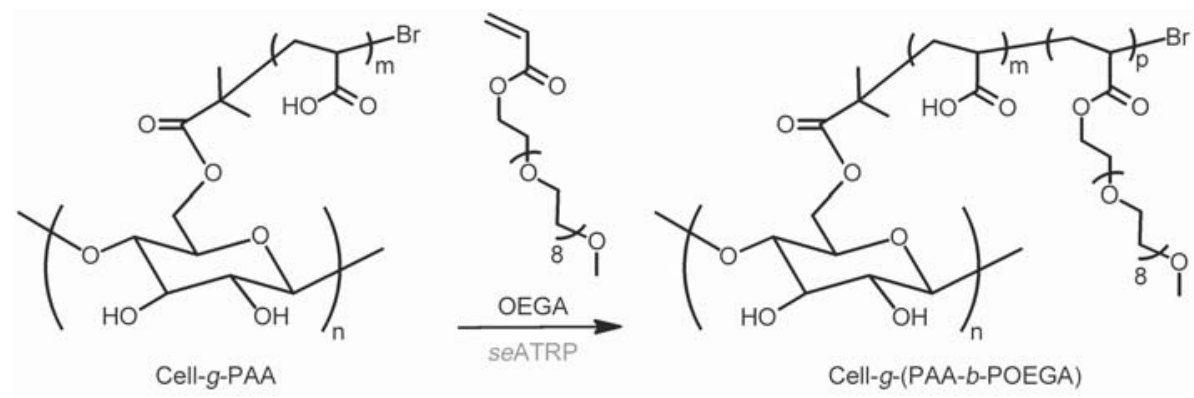

Figure 4. Synthesis of Cell-g-(PAA- $b$-POEGA) graft polymers via seATRP 
according to procedure described in reference [42]. The polymer samples were purified [42] and then characterized by GPC to examine the growth of the copolymer arms with monomer conversion. Furthermore, the final polymer was characterized using ${ }^{1} \mathrm{H}$ NMR.

\section{Results and discussion}

According to ${ }^{1} \mathrm{H}$ NMR analysis, provided in Figure 5, the Cell-Br macroinitiator was generated with DS of 1 indicating complete functionalization of the $-\mathrm{OH}$ group at the $b_{6}$ position. Notwithstanding, with a low probability substitution could occur at $\mathrm{b}_{2}$ and $\mathrm{b}_{3}-\mathrm{OH}$ groups, therefore substituents can be distributed among the three hydroxyls, with preference for the $-\mathrm{OH}$ group at the $\mathrm{b}_{6}$ position. The total DS of BriB is obtained by the ratio of the integral of the methyl groups at the region of $\delta=1.55-2.00 \mathrm{ppm}(6 H)$ to the integral of protons of glucose units of cellulose at the region of $\delta=3.00-5.50 \mathrm{ppm}(7 H)[2,5,43]$. DS is an important parameter that directly determines the grafting density of copolymers prepared in the subsequent step [3]. It should be noticed that, in previous studies using cellulose and its derivatives as the start-

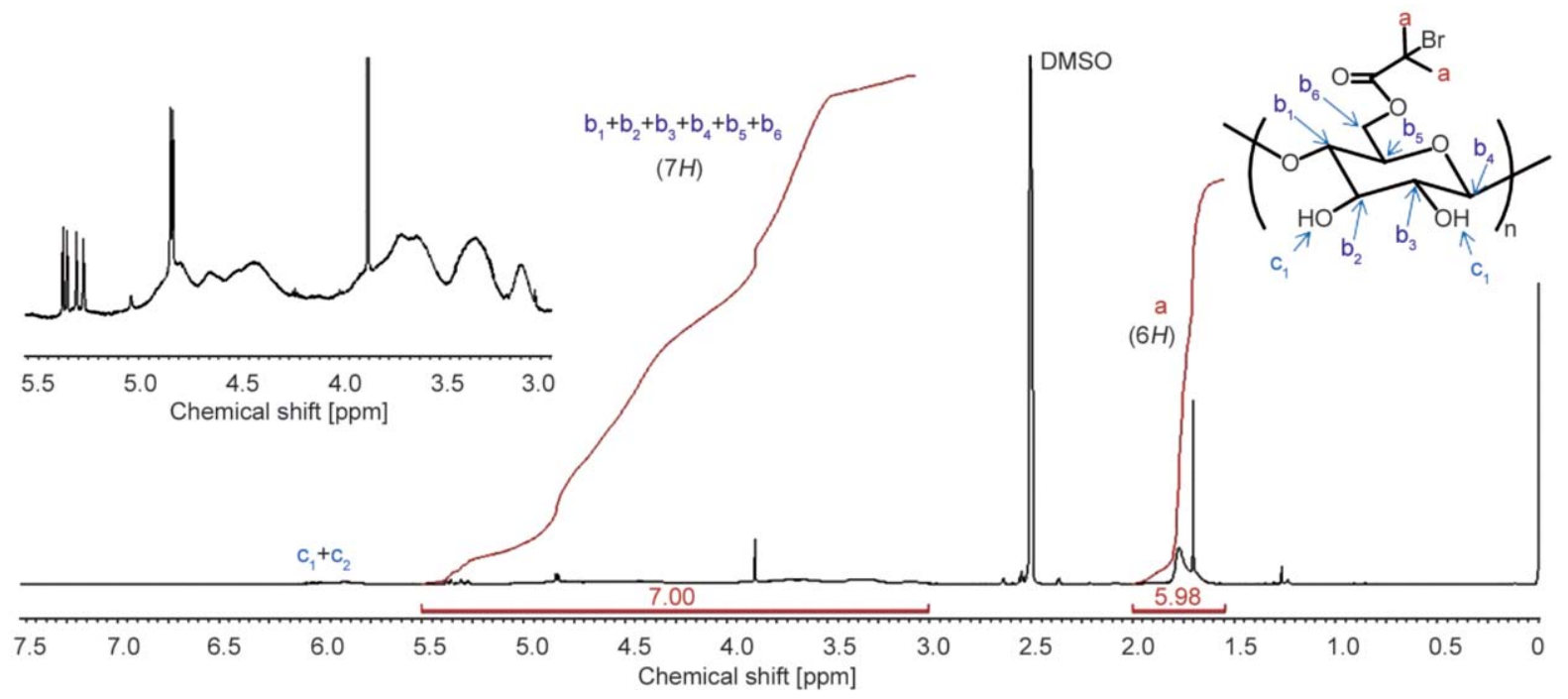

Figure 5. ${ }^{1} \mathrm{H}$ NMR analysis of Cell-Br after purification (in DMSO-d $\mathrm{d}_{6}$ )

Table 1. Summary of cellulose-based graft polymers synthesis

\begin{tabular}{|c|c|c|c|c|c|c|c|c|c|c|}
\hline Entry & {$[\mathrm{M}]_{0} /[\mathrm{MI}]_{0} /\left[\mathrm{Cu}^{\mathrm{II}} / \mathbf{L}^{(\mathrm{a})}\right]_{0}$} & $E_{\text {app }}{ }^{(b)}$ & $\begin{array}{c}k_{\mathrm{p}}^{\text {app(c) }} \\
{\left[\mathrm{h}^{-1}\right]}\end{array}$ & $\begin{array}{c}\text { Conversion }^{(\mathrm{c})} \\
{[\%]}\end{array}$ & $\begin{array}{l}M_{\mathrm{n}, \mathrm{th}}{ }^{(\mathrm{d})} \\
\left(\cdot \mathbf{1 0}^{-3}\right)\end{array}$ & $\mathbf{D P} \mathbf{P}_{\mathrm{n}, \mathrm{th}^{(\mathrm{e})}}$ & $\begin{array}{c}M_{\text {n,app }}(\mathrm{f}) \\
\left(\cdot 10^{-3}\right)\end{array}$ & $\mathbf{D P}_{\mathrm{n}, \mathrm{app}}{ }^{(\mathrm{g})}$ & $M_{\mathrm{w}} / M_{\mathrm{n}}^{(\mathrm{f})}$ & $\begin{array}{l}f_{\mathrm{i}}^{(\mathbf{h})} \\
{[\%]}\end{array}$ \\
\hline 1 & $300 / 1 / 0.0090$ & $E_{\mathrm{pc}}-55 \mathrm{mV}$ & 1.087 & 99 & 37.9 & 296 & 38.2 & 298 & 1.14 & 99 \\
\hline 2 & $300 / 1 / 0.0090$ & 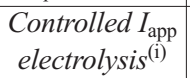 & 0.967 & 98 & 37.7 & 294 & 38.1 & 297 & 1.17 & 99 \\
\hline $3^{(\mathrm{j})}$ & - & - & - & - & 21.2 & 294 & 21.3 & 296 & 1.17 & 99 \\
\hline 4 & $120 / 1 / 0.0036$ & $E_{\mathrm{pc}}-65 \mathrm{mV}$ & 0.801 & 96 & $\begin{array}{l}55.2 \\
(76.4)^{(\mathrm{k})}\end{array}$ & 115 & $\begin{array}{c}57.5 \\
(78.8)^{(1)}\end{array}$ & 120 & 1.11 & 96 \\
\hline 5 & $120 / 1 / 0.0036$ & $\begin{array}{l}\text { Controlled } I_{\mathrm{app}} \\
\text { electrolysis }(\mathrm{m})\end{array}$ & 0.780 & 96 & $\begin{array}{l}55.0 \\
(76.2)^{(\mathrm{k})}\end{array}$ & 115 & $\begin{array}{l}57.2 \\
(78.5)^{(1)}\end{array}$ & 119 & 1.13 & 97 \\
\hline
\end{tabular}

General reaction conditions: $T=50^{\circ} \mathrm{C}\left(\right.$ except entry $\left.3: T=80^{\circ} \mathrm{C}\right) ; V_{\text {tot }}=20 \mathrm{~mL}$ (except entry 3: $V_{\text {tot }}=80 \mathrm{~mL}$ and entries 4-5: $V_{\text {tot }}=15 \mathrm{~mL}$ ); $t=4 \mathrm{~h}$ (except entry $3: t=72 \mathrm{~h}) ;[\mathrm{M}]_{0}:[t \mathrm{BA}]_{0}=3.4 \mathrm{M}$ (except entry $3: \mathrm{n} / \mathrm{a}$ and entries $\left.4-5:[\mathrm{OEGA}]_{0}=0.7 \mathrm{M}\right) ;[\mathrm{MI}]_{0}:[\mathrm{Cell}-\mathrm{Br}]_{0}=11.4 \mathrm{mM}$ calculated per $67-\mathrm{Br}$ (except entry 3: n/a and entries 4-5: [Cell-g-PAA-Br $]_{0}=5.8 \mathrm{mM}$ per $\left.67-\mathrm{Br}\right) ;\left[\mathrm{Cu}{ }^{\mathrm{II}} / \mathrm{L}\right]_{0}=0.10 \mathrm{mM}$ (except entry 3 : $\mathrm{n} / \mathrm{a}$ and entries 4-5: $\left.\left[\mathrm{Cu}^{\mathrm{II}} \mathrm{Br}_{2} / 2 \mathrm{TPMA}\right]_{0}=0.02 \mathrm{mM}\right) ;[\mathrm{TBAP}]_{0}=0.2 \mathrm{M}$. seATRP under constant potential electrolysis conditions $(\mathrm{WE}=\mathrm{Pt}$, $\mathrm{CE}=\mathrm{Al}, \mathrm{RE}=\mathrm{SCE}$ ): entry 1 and 4; seATRP under constant current electrolysis conditions (WE and CE without RE): entry 2 and 5. ${ }^{(a)} \mathrm{Cu}^{\mathrm{II}} / \mathrm{L}=\mathrm{Cu}^{\mathrm{II}} \mathrm{Br}_{2} / 2 \mathrm{TPMA}$; ${ }^{(\mathrm{b})} E_{\text {app }}$ were selected based on $\mathrm{CV}(v=100 \mathrm{mV} / \mathrm{s}) ;{ }^{\text {(c) }}$ monomer conversion and apparent propagation constants $\left(k_{\mathrm{p}}{ }^{\text {app }}\right)$ were determined by NMR $[30] ;{ }^{(\mathrm{d})} M_{\mathrm{n}, \text { th }}=\left(\right.$ conversion $\left.\cdot[\mathrm{M}]_{0}\right) /[\mathrm{MI}]_{0} \cdot M_{\text {monomer, }}$, where $[\mathrm{M}]_{0}$ and $[\mathrm{MI}]_{0}$ are the initial monomer and initiation site concentrations, respectively; ${ }^{(e)}$ theoretical degree of polymerization per arm from monomer to initiation site ratio and monomer conversion: $\mathrm{DP}_{\mathrm{n}, \mathrm{th}}($ per arm $)=\left(\right.$ conversion $\left.\cdot[\mathrm{M}]_{0}\right) /[\mathrm{MI}]_{0}[42]$; ${ }^{(\mathrm{f})}$ apparent $M_{\mathrm{n}}$ and $M_{\mathrm{w}} / M_{\mathrm{n}}$ of the arms cleaved from the (co)polymers executed by THF GPC; ${ }^{(\mathrm{g})}$ experimental DP of arm from dividing $M_{\mathrm{n} \text {,app }}$ by the molar mass of the polymer's reiterating unit: $\mathrm{DP}_{\mathrm{n} \text {,app }}\left(\right.$ per arm) $=M_{\mathrm{n} \text {,app }}$ (arm) $/ M_{\text {monomer }}[44]$; ${ }^{(h)}$ apparent efficiency of initiation calculated as: $f_{\mathrm{i}}=\left(\mathrm{DP}_{\mathrm{n}, \text { theo }}(\right.$ per arm $) / \mathrm{DP}_{\mathrm{n}, \text { app }}($ per arm $\left.)\right) \cdot 100 \%[45] ;{ }^{(\mathrm{i})} I_{\mathrm{app}}=-1.32$, $-0.90,-0.54,-0.41,-0.28,-0.22,-0.16,-0.12,-0.08,-0.06$, and $-0.05 \mathrm{~mA}$ for each steps; ${ }^{(j)}$ hydrolysis of PtBA blocks to PAA blocks [42]; ${ }^{(\mathrm{k})}$ theoretical $M_{\mathrm{n}}$ was determined (equation ${ }^{(\mathrm{d})}$ ) and reduced by the value of PAA (from entry 3); (l)apparent $M_{\mathrm{n}}$ was determined by THF GPC and reduced by the value of PBA (from entry 3 ); ${ }^{(\mathrm{m})} I_{\text {app }}=-1.46,-1.05,-0.77,-0.54,-0.38,-0.27,-0.20,-0.15,-0.11,-0.08$, $-0.05,-0.04,-0.03$, and $-0.02 \mathrm{~mA}$ for each steps. 
ing materials, the higher DS of BriB was very difficult to obtain and its values were often less than 1 $[2,5,43]$, this is mainly due to the occupation on hydroxyl groups of cellulose by ester or ether groups. Here it was demonstrated new proposition of synthesis of graft polymers by seATRP using $30 \mathrm{ppm}$ of $\mathrm{Cu}^{\mathrm{II}} / \mathrm{L}$. Table 1 summarizes the results of the graft polymers synthesis using the cellulose-based macroinitiator $\left(M_{\mathrm{n}}=20800, M_{\mathrm{w}} / M_{\mathrm{n}}=2.16\right)$.

\subsection{Synthesis of cellulose-based graft polymers}

The preparation of the cellulose-based polymer brushes with $\mathrm{P} t \mathrm{BA}$ side chains via seATRP under constant potential electrolysis and 11-step constant current electrolysis conditions were carried out (Table 1, entries 1-2, Figure 6 and 7). In order to determine the arm lengths of synthetized polymers, the arms were cleaved off the cellulose chain by acid solvolysis of the ester groups (Figure 8) [44]. Following the solvolysis, only polymers with narrow molecular weight distributions $\left(M_{\mathrm{w}} / M_{\mathrm{n}}<1.17\right.$; Figure 7, Table 1, entries 1-2) were observed, which indicates the cleavage reactions were nearly quantitative, what means that all chains growing to approximately equal lengths after a given period of time (initiation efficiency were close to $99 \%$ ). In both cases first-order kinetic plots were observed (Figure 6b), furthermore the $M_{\mathrm{n}}$ of PtBA side chain increased linearly with the monomer conversion (Figure 6c) providing polymers with low $M_{\mathrm{w}} / M_{\mathrm{n}}$ values (Figure 6c and 7).

By selective hydrolysis of the P $t$ BA block of side chains, cellulose-based brushes with PAA arms were obtained (for each PAA arms: $M_{\mathrm{n}}=21300, M_{\mathrm{w}} / M_{\mathrm{n}}=$ 1.17; Table 1, entry 3 ). Cleavage was again verified by GPC (Figure 9) and ${ }^{1} \mathrm{H}$ NMR (Figure 13). The initiation efficiency was close to $99 \%$ (Table 1, entry 3 ).
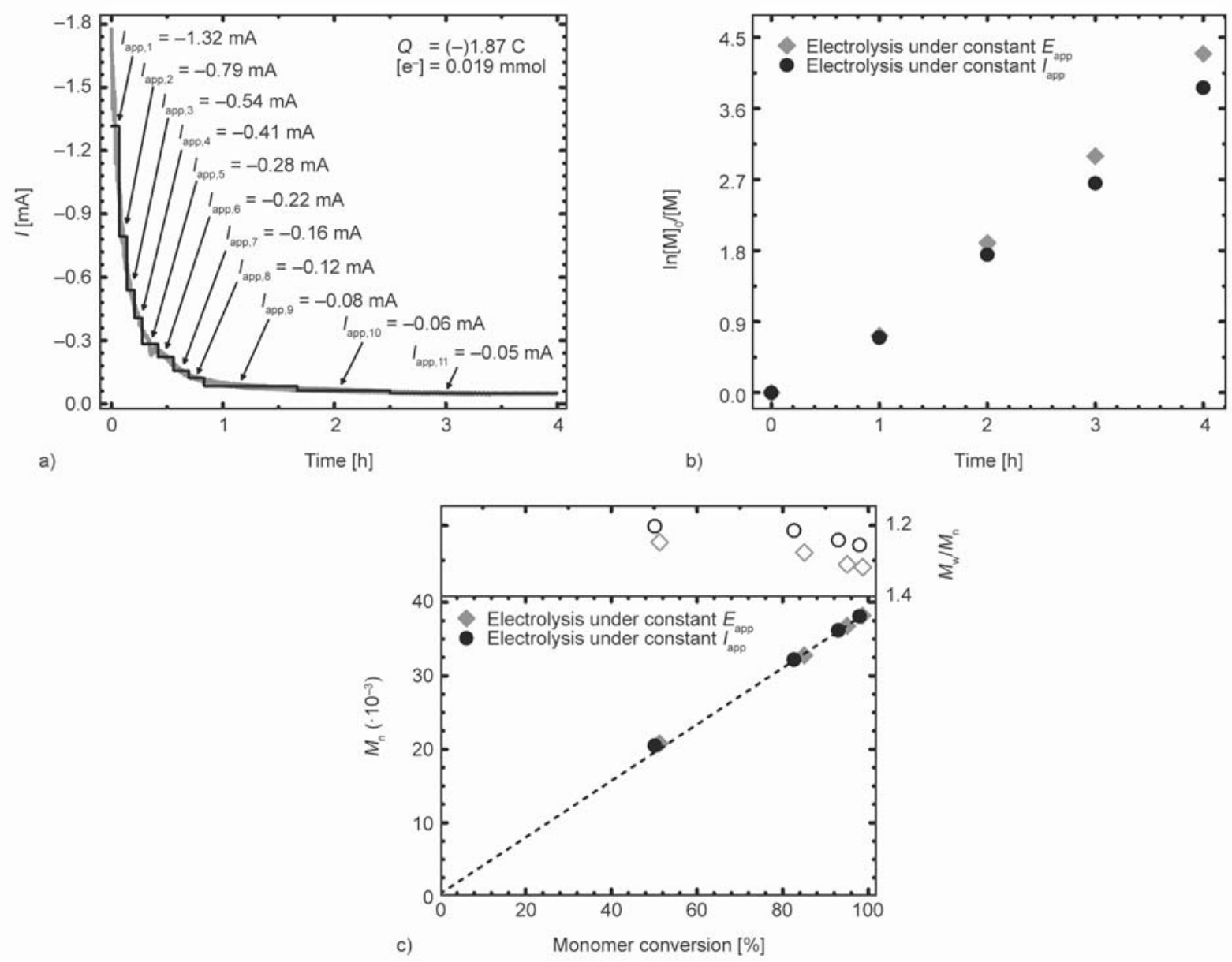

Figure 6. Synthesis of cellulose-based graft polymers by seATRP; (a) electrolysis results from applied potential conditions (grey line) and applied current (black line), (b) first-order kinetic plot of monomer conversion versus time, and (c) $M_{\mathrm{n}}$ and $M_{\mathrm{w}} / M_{\mathrm{n}}$ of side chain PtBA versus monomer conversion by constant potential and constant current electrolysis conditions. Table 1, entries 1-2. 

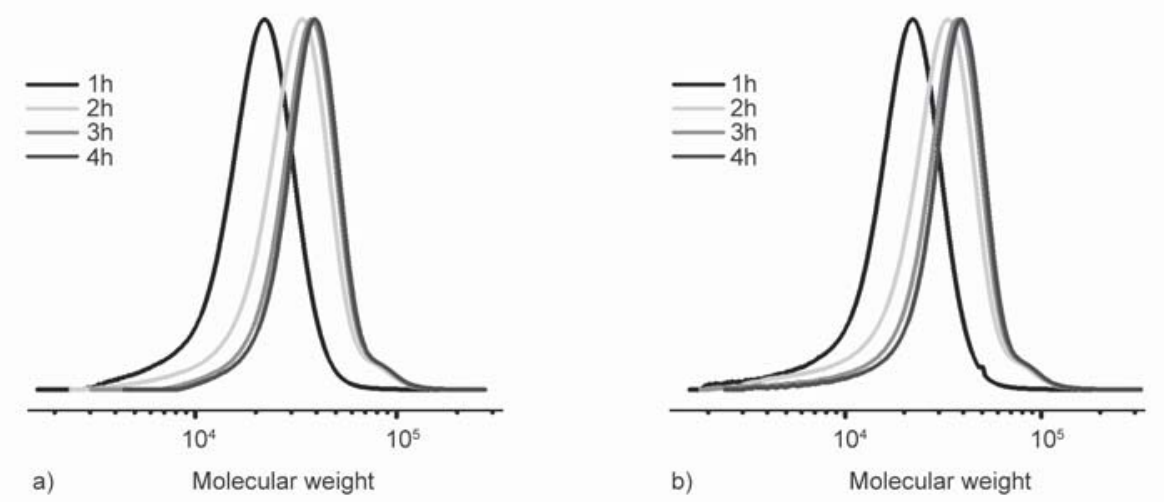

Figure 7. GPC traces of PtBA arms cleaved from the graft polymers (Table 1, entries 1-2) at various levels of monomer conversion in polymerization under constant potential seATRP (a) and constant current seATRP (b)

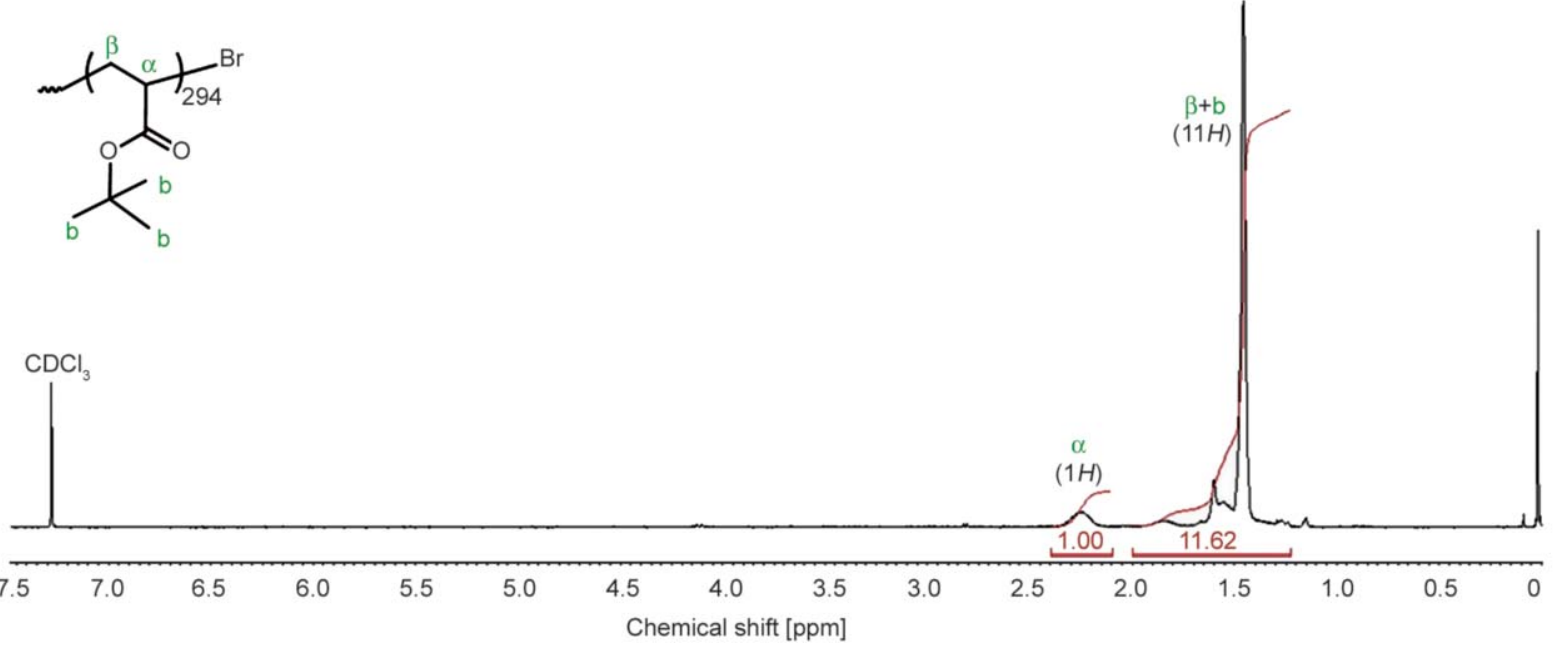

Figure 8. ${ }^{1} \mathrm{H}$ NMR spectrum of $\mathrm{P} t \mathrm{BA}$ arms cleaved from the Cell- $g$ - $\mathrm{P} t \mathrm{BA}_{294}$ graft polymer (in $\mathrm{CDCl}_{3}$; Table 1 , entry 2 )

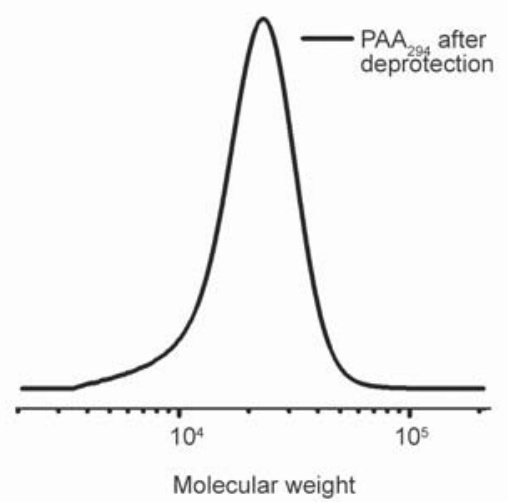

Figure 9. GPC traces of PAA arms cleaved from the cellulose-based graft polymers (Table 1, entries 3 )

These new polymer brushes are promising precursors for doubly-responsive polymers, as discussed in the next section.

\subsection{Synthesis of cellulose-based graft copolymers}

Finally, the chain extension of Cell-g-PAA macromolecule initiator (Table 1, entry 3 ) with OEGA as the potentially temperature-responsive monomer was conducted under constant potential/current preparative electrolysis conditions (Table 1, entries 4-5, Figure 10 and 11).

Also in the case of OEGA polymerizations, blocking initiation efficiency were close to 96-97\% (Table 1, entries 4-5), linear first-order plot were observed (Figure 10b) and GPC traces demonstrated efficient chain extension with OEGA (Figure 11), what is an evidence that the bromine groups are maintained during the polymerization of $t \mathrm{BA}$.

\section{3. ${ }^{1} \mathrm{H}$ NMR characterization of cellulose-based (co)polymers}

The chemical structure of the Cell-g-P $t \mathrm{BA}_{294}$ graft polymer (Table 1, entry 2), Cell-g-PAA 294 graft polymer (Table 1, entry 3), and Cell-g-(PAA $294-b$ POEGA $_{115}$ ) graft copolymer (Table 1, entry 5) were confirmed by ${ }^{1} \mathrm{H}$ NMR spectroscopy (Figure 12-14). The ${ }^{1} \mathrm{H}$ NMR spectrum shown in Figure 12 confirms the structure of Cell- $g$-P $t \mathrm{BA}_{294}$ brush-shaped polymer obtained through constant current seATRP (Table 1, entry 2). It was shown, that the chemical 

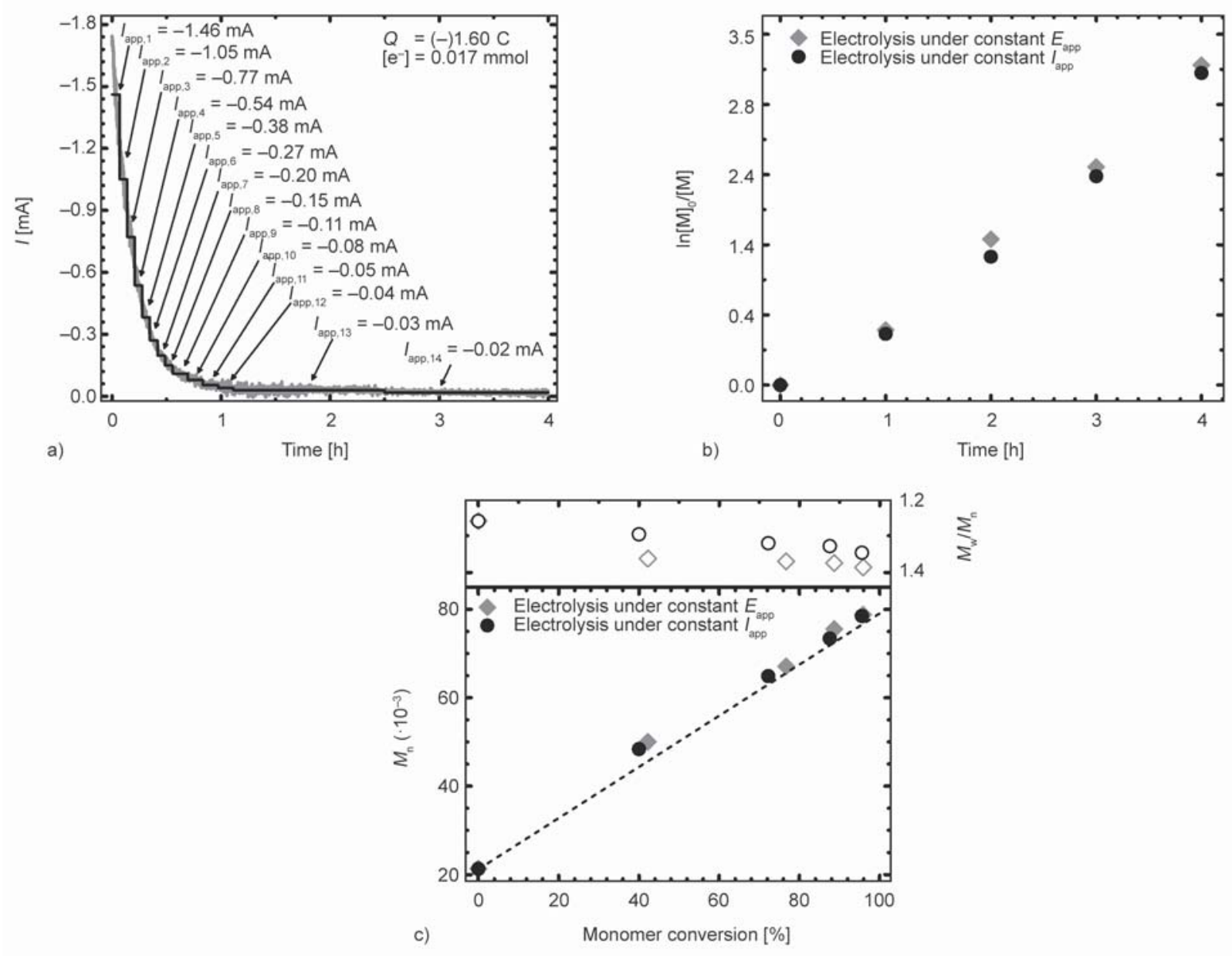

Figure 10. Synthesis of cellulose-based graft copolymers by seATRP; (a) electrolysis results from applied potential conditions (grey line) and applied current (black line), (b) first-order kinetic plot of monomer conversion versus time, and (c) $M_{\mathrm{n}}$ and $M_{\mathrm{w}} / M_{\mathrm{n}}$ of side chain PAA- $b$-P $t$ BA versus monomer conversion by constant potential and constant current electrolysis conditions. Table 1 , entries 4-5.
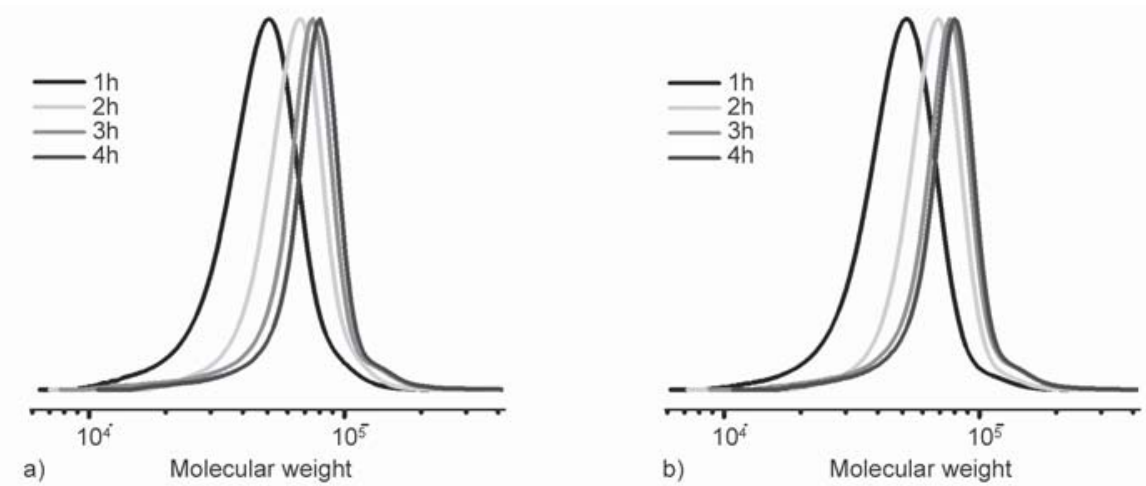

Figure 11. GPC traces of PAA- $b$-POEGA arms cleaved from the graft polymers (Table 1, entries 4-5) at various levels of monomer conversion in polymerization under constant potential seATRP (a) and constant current seATRP (b)

shifts, $1.28-2.00$ and $2.10-2.40 \mathrm{ppm}$, are attributed to the $-\mathrm{CH}_{2}-(\beta),-\mathrm{CH}_{3}(\mathrm{~b})$, and $-\mathrm{CH}-(\alpha)$ of $\mathrm{P} t \mathrm{BA}$ arms [46]. As shown in Figure 13, the disappearance of the characteristic strong peak at $\sim 1.44 \mathrm{ppm}$ corresponding to the methyl protons of the $t$-butyl group demonstrates the successful hydrolysis of $\mathrm{P} t \mathrm{BA}$ block of the side chains [39-42]. In this spectrum the chemical shift, $11.33-12.87 \mathrm{ppm}$ is attributed to the
$-\mathrm{OH}\left(\mathrm{c}^{\prime}\right)$ group indicating the presence of PAA arms [47]. While, in the ${ }^{1} \mathrm{H}$ NMR spectrum (Figure 14) of Cell-g-(PAA $294-b$-POEGA 115$)$ brush-shaped block copolymer (Table 1 , entry 5 ), the chemical shifts, $1.28-2.00,2.10-2.40,3.18-3.26,3.26-3.35,3.45-$ 3.72, and 3.90-4.25 ppm, are attributed to the $-\mathrm{CH}_{2}-$ $\left(\beta^{\prime \prime}\right),-\mathrm{CH}-\left(\alpha^{\prime \prime}\right),-\mathrm{OCH}_{3}(\mathrm{e}),-\mathrm{O}-\mathrm{CH}_{2}-\mathrm{CH}_{2}-\mathrm{OCO}-$ (f), $-\mathrm{CH}_{2}$ - from poly(ethylene glycol) backbone (g), 

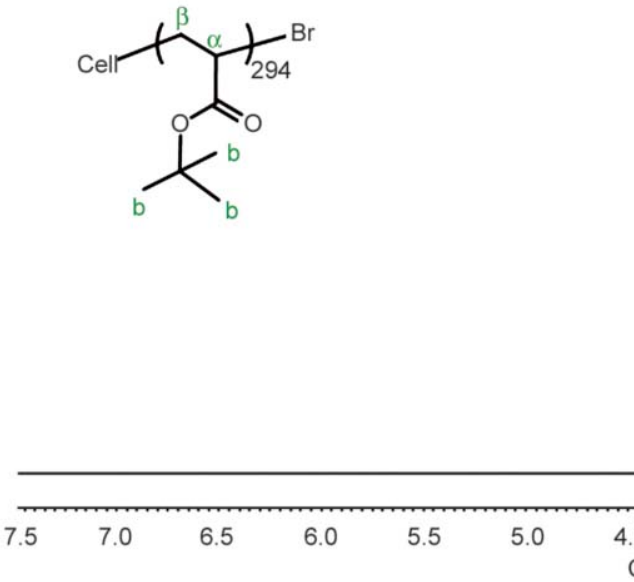

$\begin{array}{lcr}4.5 & 4.0 & 3.5 \\ \text { Chemical } & \text { shift } & {[\mathrm{ppm}]}\end{array}$

Figure 12. ${ }^{1} \mathrm{H}$ NMR spectrum of cellulose-based polymers with $\mathrm{P} t \mathrm{BA}$ arms (Cell-g-P $\left.t \mathrm{BA} 294\right)$. Table 1 , entry 2.

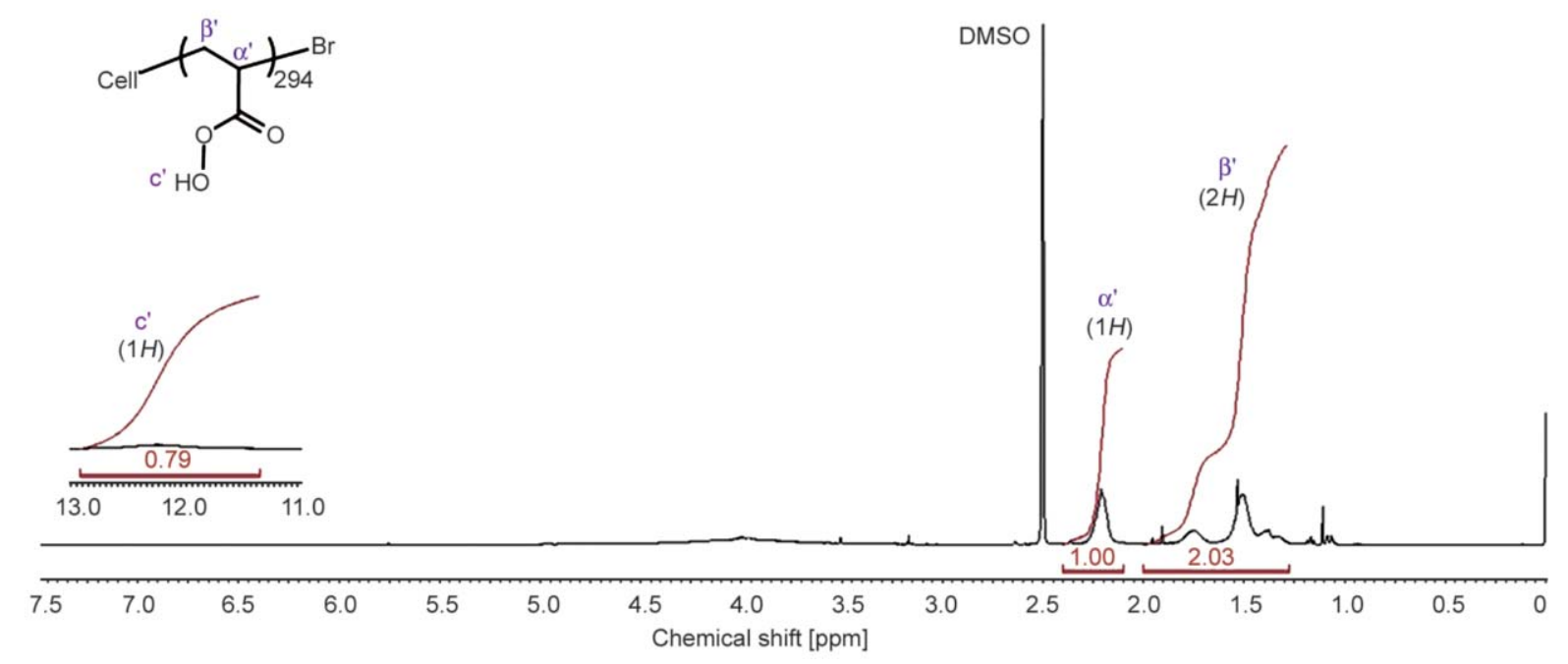

Figure 13. ${ }^{1} \mathrm{H}$ NMR spectrum of cellulose-based polymers with PAA arms (Cell-g-PAA 294$)$. Table 1, entry 3.

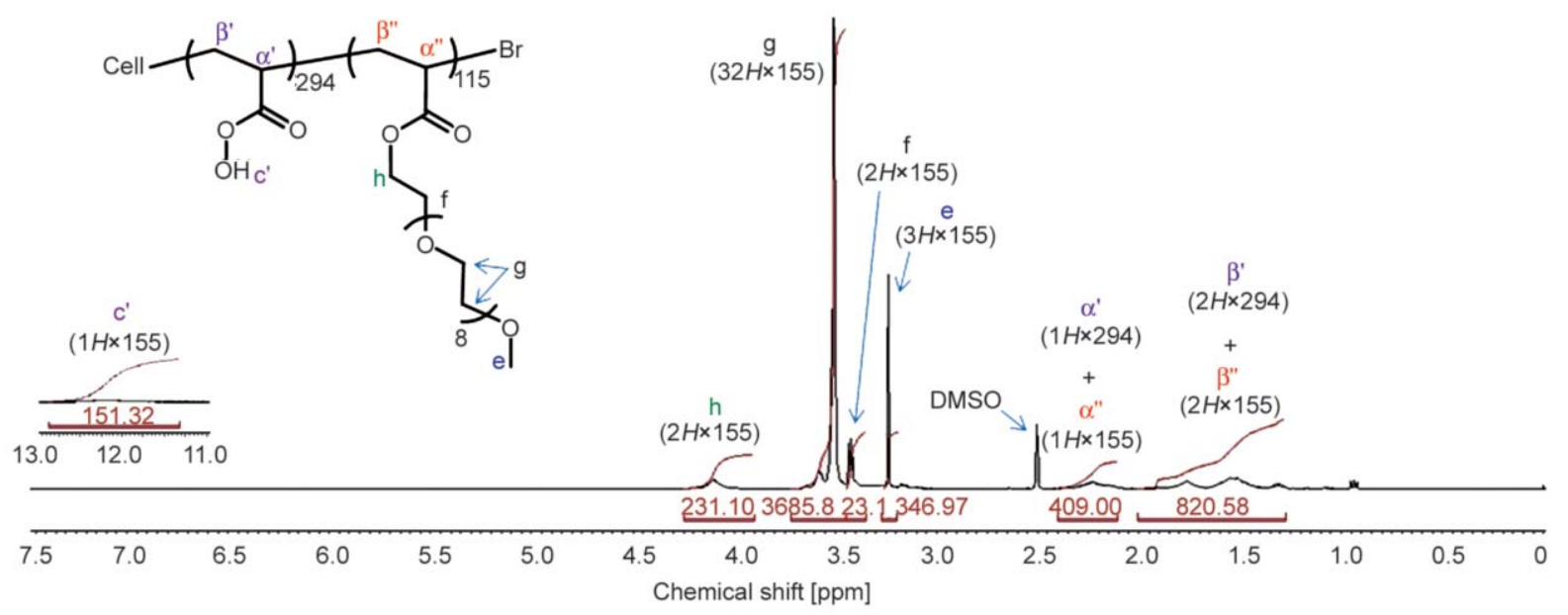

Figure 14. ${ }^{1} \mathrm{H}$ NMR spectrum of cellulose-based copolymers with PAA- $b$-POEGA arms (Cell-g-(PAA $294-b$-POEGA 115$\left.)\right)$. Table 1, entry 5.

and $-\mathrm{O}-\mathrm{CH}_{2}-\mathrm{CH}_{2}-\mathrm{OCO}-(\mathrm{h})$ groups of POEGA arms, clearly indicating the presence of POEGA chains [48-50].

\section{Conclusions}

Controlled PAA- $b$-POEGA arms brush-shaped block copolymers were for the first time successfully pre- 
pared via simplified electrochemically mediated atom transfer radical polymerization with low concentrations of catalyst ( $30 \mathrm{ppm}$ of $\mathrm{Cu}^{\mathrm{II}}$ species) under both constant potential and constant current electrolysis conditions. The use of these techniques provided similar results, producing polymers with molecular weight evolution close to theoretical values, while generating arms of brushes with narrow MWDs. Chain extension of the initially formed hydrophilic brush-like polymer with a potentially temperature-responsive monomer (OEGA), confirmed the preservation of terminal halogen end group during the seATRP of acrylates. The results from ${ }^{1} \mathrm{H}$ NMR spectral studies support the formation of brush-like block (co)polymers. These new polymer brushes are promising candidates for potential applications in biomedical fields, such as drug delivery, and antifouling coatings.

\section{Acknowledgments}

Financial support from U-718/DS and U-771/DS/M is gratefully acknowledged. NMR spectra were recorded in the Laboratory of Spectrometry, Faculty of Chemistry, Rzeszow University of Technology and were financed from DS budget.

\section{References}

[1] Klemm D., Heublein B., Fink H-P., Bohn A.: Cellulose: Fascinating biopolymer and sustainable raw material. Angewandte Chemie International Edition, 44, 3358 3393 (2005).

https://doi.org/10.1002/anie.200460587

[2] Meng T., Gao X., Zhang J., Yuan J., Zhang Y., He J.: Graft copolymers prepared by atom transfer radical polymerization (ATRP) from cellulose. Polymer, 50, 447-454 (2009). https://doi.org/10.1016/j.polymer.2008.11.011

[3] Raus V., Štěpánek M., Uchman M., Šlouf M., Látalová P., Čadová E., Netopilík M., Kř́iž J., Dybal J., Vlček P.: Cellulose-based graft copolymers with controlled architecture prepared in a homogeneous phase. Journal of Polymer Science Part A: Polymer Chemistry, 49, 4353 4367 (2011). https://doi.org/10.1002/pola.24876

[4] Kar N., Liu H., Edgar K. J.: Synthesis of cellulose adipate derivatives. Biomacromolecules, 12, 1106-1115 (2011). https://doi.org/10.1021/bm101448f

[5] Tang E., Du K., Feng X., Yuan M., Liu S., Zhao D.: Controlled synthesis of cellulose-graft-poly[2-(diethylamino)-ethyl methacrylate] by ATRP in ionic liquid [AMIM]Cl and its $\mathrm{pH}$-responsive property. European Polymer Journal, 66, 228-235 (2015). https://doi.org/10.1016/j.eurpolymj.2015.01.041
[6] Guo Y., Zhou J., Song Y., Zhang L.: An efficient and environmentally friendly method for the synthesis of cellulose carbamate by microwave heating. Macromolecular Rapid Communications, 30, 1504-1508 (2009). https://doi.org/10.1002/marc.200900238

[7] Wang M., Yuan J., Huang X., Cai X., Li L., Shen J.: Grafting of carboxybetaine brush onto cellulose membranes via surface-initiated ARGET-ATRP for improving blood compatibility. Colloids and Surfaces B: Biointerfaces, 103, 52-58 (2013).

https://doi.org/10.1016/j.colsurfb.2012.10.025

[8] Hsu C. F., Kilmartin P. A.: Antioxidant capacity of robust polyaniline-ethyl cellulose films. Reactive and Functional Polymers, 72, 814-822 (2012). https://doi.org/10.1016/j.reactfunctpolym.2012.07.015

[9] Westlund R., Carlmark A., Hult A., Malmström E., Saez I. M.: Grafting liquid crystalline polymers from cellulose substrates using atom transfer radical polymerization. Soft Matter, 3, 866-871 (2007).

https://doi.org/10.1039/B700630F

[10] Yan L., Ishihara K.: Graft copolymerization of 2methacryloyloxyethyl phosphorylcholine to cellulose in homogeneous media using atom transfer radical polymerization for providing new hemocompatible coating materials. Journal of Polymer Science Part A: Polymer Chemistry, 46, 3306-3313 (2008).

https://doi.org/10.1002/pola.22670

[11] Hansson S., Carlmark A., Malmström E., Fogelström L.: Toward industrial grafting of cellulosic substrates via ARGET ATRP. Journal of Applied Polymer Science, 132, 41434/1-41434/10 (2015).

https://doi.org/10.1002/app.41434

[12] Larsson E., Pendergraph S. A., Kaldéus T., Malmström E., Carlmark A.: Cellulose grafting by photoinduced controlled radical polymerisation. Polymer Chemistry, 6, 1865-1874 (2015). https://doi.org/10.1039/C4PY01618A

[13] Sui X., Yuan J., Zhou M., Zhang J., Yang H., Yuan W., Wei T., Pan C.: Synthesis of cellulose-graft-poly $(N, N$ dimethylamino-2-ethyl methacrylate) copolymers via homogeneous ATRP and their aggregates in aqueous media. Biomacromolecules, 9, 2615-2620 (2008). https://doi.org/10.1021/bm800538d

[14] Ifuku S., Kadla J. F.: Preparation of a thermosensitive highly regioselective cellulose/ $N$-isopropylacrylamide copolymer through atom transfer radical polymerization. Biomacromolecules, 9, 3308-3313 (2008). https://doi.org/10.1021/bm800911w

[15] Cui G., Li Y., Shi T., Gao Z., Qiu N., Satoh T., Kakuchi T., Duan Q.: Synthesis and characterization of Eu(III) complexes of modified cellulose and poly $(N$-isopropylacrylamide). Carbohydrate Polymers, 94, 77-81 (2013). https://doi.org/10.1016/j.carbpol.2013.01.045 
[16] Ma Z-Y., Jia X., Zhang G-X., Hu J-M., Zhang X-L., Liu Z-Y., Wang H-Y., Zhou F.: pH-Responsive controlledrelease fertilizer with water retention via atom transfer radical polymerization of acrylic acid on mussel-inspired initiator. Journal of Agricultural and Food Chemistry, 61, 5474-5482 (2013).

https://doi.org/10.1021/jf401102a

[17] Dong R., Krishnan S., Baird B. A., Lindau M., Ober C. K.: Patterned biofunctional poly(acrylic acid) brushes on silicon surfaces. Biomacromolecules, 8, 3082-3092 (2007). https://doi.org/10.1021/bm700493v

[18] Li C. Y., Wang W. C., Xu F. J., Zhang L. Q., Yang W. T.: Preparation of $\mathrm{pH}$-sensitive membranes via dopamine-initiated atom transfer radical polymerization. Journal of Membrane Science, 367, 7-13 (2011). https://doi.org/10.1016/j.memsci.2010.09.057

[19] Ramkissoon-Ganorkar C., Liu F., Baudyš M., Kim S. $\mathrm{W}$.: Modulating insulin-release profile from $\mathrm{pH} /$ thermosensitive polymeric beads through polymer molecular weight. Journal of Controlled Release, 59, 287 298 (1999).

https://doi.org/10.1016/S0168-3659(99)00006-1

[20] Kurkuri M. D., Aminabhavi T. M.: Poly(vinyl alcohol) and poly(acrylic acid) sequential interpenetrating network $\mathrm{pH}$-sensitive microspheres for the delivery of diclofenac sodium to the intestine. Journal of Controlled Release, 96, 9-20 (2004).

https://doi.org/10.1016/j.jconrel.2003.12.025

[21] Gao X., He C., Xiao C., Zhuang X., Chen X.: Biodegradable $\mathrm{pH}$-responsive polyacrylic acid derivative hydrogels with tunable swelling behavior for oral delivery of insulin. Polymer, 54, 1786-1793 (2013). https://doi.org/10.1016/j.polymer.2013.01.050

[22] Harris J. M., Chess R. B.: Effect of pegylation on pharmaceuticals. Nature Reviews Drug Discovery, 2, 214 221 (2003).

https://doi.org/10.1038/nrd1033

[23] Bozukova D., Pagnoulle C., De Pauw-Gillet M-C., Ruth N., Jérôme R., Jérôme C.: Imparting antifouling properties of poly(2-hydroxyethyl methacrylate) hydrogels by grafting poly(oligoethylene glycol methyl ether acrylate). Langmuir, 24, 6649-6658 (2008).

https://doi.org/10.1021/la7033774

[24] Beija M., Li Y., Lowe A. B., Davis T. P., Boyer C.: Factors influencing the synthesis and the post-modification of PEGylated pentafluorophenyl acrylate containing copolymers. European Polymer Journal, 49, 3060-3071 (2013).

https://doi.org/10.1016/j.eurpolymj.2013.05.003

[25] Yeniad B., Ryskulova K., Fournier D., Lyskawa J., Cooke G., Woisel P., Hoogenboom R.: Complexation of thermoresponsive dialkoxynaphthalene end-functionalized poly(oligoethylene glycol acrylate)s with $\mathrm{CBPQT}^{4+}$ in water. Polymer Chemistry, 7, 3681-3690 (2016). https://doi.org/10.1039/C6PY00303F
[26] Matyjaszewski K., Jo S. M., Paik H-J., Shipp D. A.: An investigation into the $\mathrm{CuX} / 2,2^{\prime}$-bipyridine $(\mathrm{X}=\mathrm{Br}$ or $\mathrm{Cl})$ mediated atom transfer radical polymerization of acrylonitrile. Macromolecules, 32, 6431-6438 (1999). https://doi.org/10.1021/ma9905526

[27] Król P., Chmielarz P.: Recent advances in ATRP methods in relation to the synthesis of copolymer coating materials. Progress in Organic Coatings, 77, 913-948 (2014). https://doi.org/10.1016/j.porgcoat.2014.01.027

[28] Matyjaszewski K., Tsarevsky N. V.: Macromolecular engineering by atom transfer radical polymerization. Journal of the American Chemical Society, 136, 65136533 (2014).

https://doi.org/10.1021/ja408069v

[29] Boyer C., Corrigan N. A., Jung K., Nguyen D., Nguyen T-K., Adnan N. N. M., Oliver S., Shanmugam S., Yeow J.: Copper-mediated living radical polymerization (Atom transfer radical polymerization and copper( 0 ) mediated polymerization): From fundamentals to bioapplications. Chemical Reviews, 116, 1803-1949 (2016).

https://doi.org/10.1021/acs.chemrev.5b00396

[30] Chmielarz P., Park S., Simakova A., Matyjaszewski K.: Electrochemically mediated ATRP of acrylamides in water. Polymer, 60, 302-307 (2015).

https://doi.org/10.1016/j.polymer.2015.01.051

[31] Park S., Chmielarz P., Gennaro A., Matyjaszewski K.: Simplified electrochemically mediated atom transfer radical polymerization using a sacrificial anode. Angewandte Chemie International Edition, 54, 2388-2392 (2015).

https://doi.org/10.1002/anie.201410598

[32] Chmielarz P., Krys P., Park S., Matyjaszewski K.: PEO$b$-PNIPAM copolymers via SARA ATRP and eATRP in aqueous media. Polymer, 71, 143-147 (2015).

https://doi.org/10.1016/j.polymer.2015.06.042

[33] Chmielarz P., Sobkowiak A., Matyjaszewski K.: A simplified electrochemically mediated ATRP synthesis of PEO- $b$-PMMA copolymers. Polymer, 77, 266-271 (2015).

https://doi.org/10.1016/j.polymer.2015.09.038

[34] Chmielarz P., Park S., Sobkowiak A., Matyjaszewski K.: Synthesis of $\beta$-cyclodextrin-based star polymers via a simplified electrochemically mediated ATRP. Polymer, 88, 36-42 (2016).

https://doi.org/10.1016/j.polymer.2016.02.021

[35] Loske S., Lutz A., Striouk S., Wolf B. A.: Fractionation of unsubstituted cellulose from solutions in either Nitren or $(N, N$-dimethylacetamide $+\mathrm{LiCl})$. Macromolecular Chemistry and Physics, 201, 1940-1945 (2000). https://doi.org/10.1002/1521-3935(20001001)201:15<1940:: AID-MACP1940>3.0.CO;2-5

[36] Xia J., Zhang X., Matyjaszewski K.: Synthesis of starshaped polystyrene by atom transfer radical polymerization using an 'arm first' approach. Macromolecules, 32, 4482-4484 (1999). https://doi.org/10.1021/ma9900378 
[37] Zhang H., Wu J., Zhang J., He J.: 1-Allyl-3-methylimidazolium chloride room temperature ionic liquid: A new and powerful nonderivatizing solvent for cellulose. Macromolecules, 38, 8272-8277 (2005).

https://doi.org/10.1021/ma0505676

[38] Sumerlin B. S., Neugebauer D., Matyjaszewski K.: Initiation efficiency in the synthesis of molecular brushes by grafting from via atom transfer radical polymerization. Macromolecules, 38, 702-708 (2005).

https://doi.org/10.1021/ma048351b

[39] Burguière C., Pascual S., Bui C., Vairon J-P., Charleux B., Davis K. A., Matyjaszewski K., Bétremieux I.: Block copolymers of poly(styrene) and poly(acrylic acid) of various molar masses, topologies, and compositions prepared via controlled/living radical polymerization. Application as stabilizers in emulsion polymerization. Macromolecules, 34, 4439-4450 (2001). https://doi.org/10.1021/ma002066k

[40] Mori H., Seng D. C., Lechner H., Zhang M., Müller A. H. E.: Synthesis and characterization of branched polyelectrolytes. 1. Preparation of hyperbranched poly(acrylic acid) via self-condensing atom transfer radical copolymerization. Macromolecules, 35, 9270-9281 (2002). https://doi.org/10.1021/ma021159u

[41] Zhang M., Breiner T., Mori H., Müller A. H. E.: Amphiphilic cylindrical brushes with poly(acrylic acid) core and poly( $n$-butyl acrylate) shell and narrow length distribution. Polymer, 44, 1449-1458 (2003). https://doi.org/10.1016/S0032-3861(02)00774-7

[42] Plamper F. A., Becker H., Lanzendörfer M., Patel M., Wittemann A., Ballauff M., Müller A. H. E.: Synthesis, characterization and behavior in aqueous solution of star-shaped poly(acrylic acid). Macromolecular Chemistry and Physics, 206, 1813-1825 (2005).

https://doi.org/10.1002/macp.200500238

[43] Vlček P., Janata M., Látalová P., Kríž J., Čadová E., Toman L.: Controlled grafting of cellulose diacetate. Polymer, 47, 2587-2595 (2006).

https://doi.org/10.1016/j.polymer.2006.02.067
[44] Neugebauer D., Sumerlin B. S., Matyjaszewski K., Goodhart B., Sheiko S. S.: How dense are cylindrical brushes grafted from a multifunctional macroinitiator? Polymer, 45, 8173-8179 (2004).

https://doi.org/10.1016/j.polymer.2004.09.069

[45] Cheng G., Böker A., Zhang M., Krausch G., Müller A. H. E.: Amphiphilic cylindrical core-shell brushes via a 'grafting from' process using ATRP. Macromolecules, 34, 6883-6888 (2001). https://doi.org/10.1021/ma0013962

[46] Williams V. A., Ribelli T. G., Chmielarz P., Park S., Matyjaszewski K.: A silver bullet: Elemental silver as an efficient reducing agent for atom transfer radical polymerization of acrylates. Journal of the American Chemical Society, 137, 1428-1431 (2015).

https://doi.org/10.1021/ja512519j

[47] Lin X., Tang D., Yu Z., Feng Q.: Stimuli-responsive electrospun nanofibers from poly $(\mathrm{N}$-isopropylacrylamide)-co-poly(acrylic acid) copolymer and polyurethane. Journal of Materials Chemistry B, 2, 651-658 (2014).

https://doi.org/10.1039/C3TB21519A

[48] Krieg A., Pietsch C., Baumgaertel A., Hager M. D., Becer C. R., Schubert U. S.: Dual hydrophilic polymers based on (meth)acrylic acid and poly(ethylene glycol) - Synthesis and water uptake behavior. Polymer Chemistry, 1, 1669-1676 (2010). https://doi.org/10.1039/C0PY00156B

[49] Winkler M., de Espinosa L. M., Barner-Kowollik C., Meier M. A. R.: A new approach for modular polymerpolymer conjugations via Heck coupling. Chemical Science, 3, 2607-2615 (2012). https://doi.org/10.1039/C2SC20402A

[50] Basuki J. S., Esser L., Zetterlund P. B., Whittaker M. R., Boyer C., Davis T. P.: Grafting of P(OEGA) onto magnetic nanoparticles using $\mathrm{Cu}(0)$ mediated polymerization: Comparing grafting 'from' and 'to' approaches in the search for the optimal material design of nanoparticle MRI contrast agents. Macromolecules, 46, 60386047 (2013).

https://doi.org/10.1021/ma401250f 